loger at the Jewish Theological Seminary library.

Effective May 1 BiLlie I. Salter was appointed librarian of the economic growth center library in Yale University. Miss Salter reports to the associate librarian in charge of school and departmental libraries.

The appointment of Zenon Sheparovych as associate college librarian, State University College at Geneseo, has been announced.

JACOB ShUmelda, librarian of Methodist College, Fayetteville, N.C., was recently appointed social sciences bibliographer in the university library, of the University of Alberta.

Mrs. Celeste Sproul is now an acqusitions librarian in the Joint University libraries, Nashville.

\section{NECROLOGY}

B. Armstrong Claytor died in Washington, D.C., on May 23, after more than forty-one years' service to the federal government and nearly ten years in retirement. Except for his World War I service with the 351st Field Artillery in France, Mr. Claytor had devoted his entire career to the Library of Congress, chiefly as a reference librarian in the Orientalia Division under four Librarians of Congress.
RETIREMENTS

Florence Bethea, associate professor and assistant director of libraries, will retire in August after thirty-nine years at Florida State University and Florida State College for Women.

John Kenneth Cameron, chief of reader services, Air University library, Maxwell Air Force Base, Alabama, retires on June 30 , after a career in librarianship spanning almost forty years.

\section{MOVING? MARRYING? CHANGING POSITIONS?}

Please keep ALA informed when you change your address, your name, or your position.

If you cannot locate your current membership card or seem to have missed issues of your membership publications, please notify ALA.

Remember, it takes several weeks for records changes to become effective. During this period, mail will be sent to your former address.

For any membership records changes or problems, please write:

Membership Records

American Library Association

50 East Huron Street

Chicago, Illinois 60611

\title{
CUSHING-MALLOY, INC.
}

1350 North Main Street P.O. Box 632

Ann Arbor, Michigan 48107

\section{Printers of Who's Who in Library Service}

\section{LITHOPRINTER S}

Known for

QUALITY-ECONOMY-SERVICE

Let us quote on your next printing 


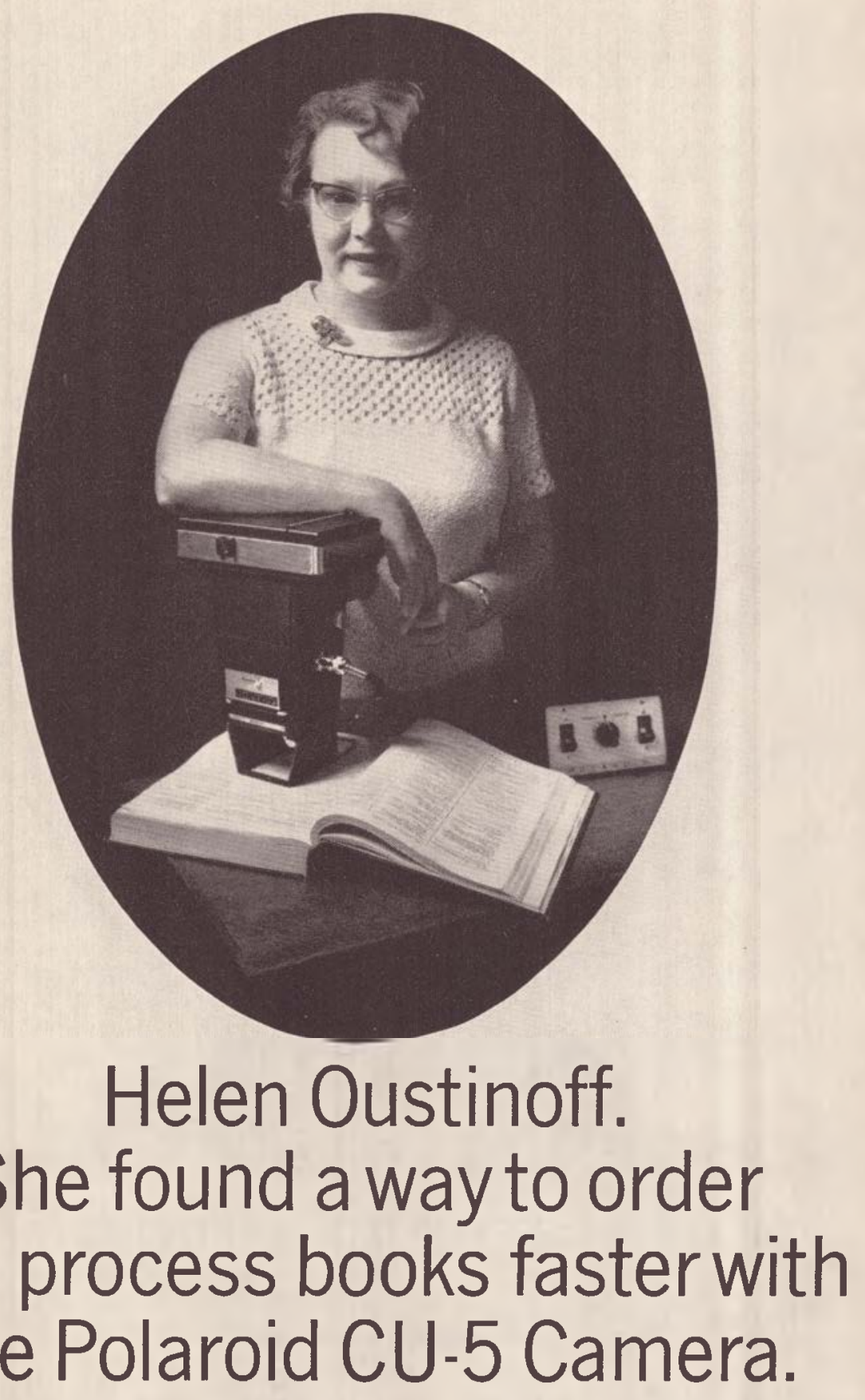

and process books faster with

the Polaroid CU-5 Camera. 
Helen Oustinoff is Assistant Director of the University of Vermont Library. She has developed a remarkable new system for proc. essing books, utilizing our Polaroid CU 5 Close-up Land Camera.

\section{No more checking or transcribing}

Here's how her system works: When a book purchase request slip is received, the searcher looks up the book in the National Union Catalog or another standard bibliography. Just as always. But she doesn't bother to correct or complete the slip. She simply photographs the entire N.U.C. entry with the CU-5 Camera.

We make that sound very easy. It is. You just center the CU.5's frame over the entry and squeeze the trigger. Pull the tabs and 15 seconds later you have an enlarged print of the whole thing. (Like the one below.) Isn't that easier than copying by hand? And faster? And more accurate?

\section{No handwriting to decipher}

Now the book order slip is typed from the Polaroid print. And the print is then filed away with a carbon of the typed order.
If the original entry happens to be in $\mathrm{He}$ brew, or something else untypable, you can simply shoot an extra print and send it along with the order.

When the book is received, it's checked against the print and the invoice is cleared.

\section{No waiting for catalog cards}

Who needs preprinted catalog cards? With this new system, you make your own. Using the Polaroid print as a guide, you can type them on an automatic typewriter. Or simply add necessary information to the print and run it through a copying machine.

The system also gets books into circulation faster because it eliminates waiting for preprinted cards. It also eliminates the job of ordering them. And the cost.

For more information about the time and cost saving features of this library system, write to: Polaroid Corporation, Dept. 113, Cambridge, Mass. 02139.

And if you have any suggestions as to new uses for our CU-5 Camera, send them along.

Who knows? You might be our next ad. POLAROID CU-5 LIBRARY CAMERA

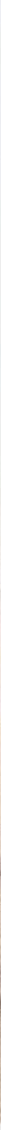

